\title{
Effects of Biochar Produced From Tropical Rice Straw, Corncob and Bamboo Tree at Different Processing Temperatures on in Vitro Rumen Fermentation and Methane Production
}

\section{Dinh Van Dung}

University of Agriculture and Forestry, Hue University

Le Duc Thao

University of Agriculture and Forestry, Hue University

Le Duc Ngoan

University of Agriculture and Forestry, Hue University

Le Dinh Phung ( $\nabla$ ldphung@hueuni.edu.vn)

University of Agriculture and Forestry, Hue University

Hynek Roubík

Czech University of Life Sciences Prague

\section{Research Article}

Keywords: biochar, tropical rice straw, corncob and bamboo tree, biomass resources, temperatures, in vitro, rumen fermentation, methane production

Posted Date: November 8th, 2021

DOl: https://doi.org/10.21203/rs.3.rs-967865/v1

License: (c) (i) This work is licensed under a Creative Commons Attribution 4.0 International License. Read Full License 


\section{Abstract}

This study aimed to evaluate the effects of biochar produced from tropical biomass resources (rice straw, corncob and bamboo) at different processing temperatures $\left(300,500\right.$ and $\left.700^{\circ} \mathrm{C}\right)$ on in vitro rumen fermentation and methane production. Treatments were arranged as a $3 \times 3$ factorial with three biomass resources and three biochar processing temperatures. Added biochar occupied $3 \%$ of the substrate (DM basic). $250 \mathrm{mg}$ of the air-dried substrate was incubated in $120 \mathrm{ml}$ bottles, which contained $25 \mathrm{ml}$ of mixed rumen fluid and buffer mineral solution. Total gas and methane production, in vitro digestibility of DM, $\mathrm{OM}$, and in vitro rumen fermentation characteristics were determined at three-time points: 4, 24 and 48 hours of the incubation. Results showed that biomass resources and processing temperatures affected gas production at 4, 24 and 48 hours of the incubation $(P<0.02)$. Interactions between biomass resources and processing temperatures affected gas production at 4 hours $(P=0.06)$ and 24 hours $(P=0.001)$. Biomass resources and processing temperatures affected methane production at different time points of the incubation, except the effect of biomass resources at 24 hours $(P=0.406)$. Increased processing temperature from 300 to $700^{\circ} \mathrm{C}$ reduced gas and methane production $(P<0.05)$. Biomass resources affected $\mathrm{OM}$ digestibility after 4 and 24 hours of incubation. Processing temperatures and their interaction with biomass resources affected OM digestibility after 48 hours of incubation $(\mathrm{P}<0.001) . \mathrm{NH}_{3}-\mathrm{N}$ concentrations at 24 and $48 \mathrm{~h}$ were highest for corncob, then rice straw, and lowest for bamboo tree derived biochar $(\mathrm{P}<0.05)$. Increased processing temperatures resulted in higher $\mathrm{NH}_{3}-\mathrm{N}$ concentrations at 24 and 48 hours of incubation $(P<0.05)$. To mitigate methane production, biomass resources and processing temperatures should be considered when utilising biochar as feed additive in ruminant diets.

\section{Introduction}

Ruminant production accounts for about $81 \%$ of total greenhouse gas (GHG) from the livestock sector ${ }^{1}$. Gaseous excretions mainly produce ruminants' GHG emissions through eructation and exhalation. Methane emissions, mainly produced through rumen microbial methanogenesis, are responsible for $90 \%$ of the GHG caused by cattle ${ }^{2}$. Archaea carry methanogenesis that converts microbial fermentation products of $\mathrm{H}_{2}$ and $\mathrm{CO}_{2}$ or formate to methane. Hydrogen serves as an electron donor for the microbial reduction of $\mathrm{CO}_{2}$ to methane. Methane production and emission mean a loss of energy for the animal, ranging from $2-12 \%$ of total gross energy intake ${ }^{3}$. The production of methane is implicated in global warming ${ }^{4}$. Thus it should be reduced. Nitrate and sulphate, other electron acceptors besides $\mathrm{CO}_{2}$ and enteric fatty acids, react to ammonia and hydrogen sulphide, respectively. However, they are toxic for the animals at higher concentrations.

Biochar is the carbon-rich solid product of pyrolysis, which is the thermal decomposition of biomass at high temperatures with little or no oxygen present ${ }^{5}$. Biochar might act as an electron acceptor and thus reduce methane production in the rumen ${ }^{6}$. Supplementing biochar (with and without biochar, different levels of biochar) has shown to decrease from 5 to $25 \%$ methane production, both in vitro and in vivo experiments ${ }^{7-10}$. Different experiments used biochars produced from various biomass resources and at different processing temperatures. Different types of biochar among experiments might be the reason for this high variation in methane production reduction. Biomass resources and pyrolysis temperature determine biochar's properties, 
thus methane production reduction ${ }^{11}$. Vietnam is rich in tropical biomass resources such as rice straw, corncob and bamboo trees that can be used to produce biochar. This research was aimed at evaluating the effects of biochar produced from tropical rice straw, corncob and bamboo tree at different processing temperatures on total gas, methane production, in vitro digestibility and rumen characteristics.

\section{Results}

\section{Gas and methane production}

Effects of biomass resources and processing temperatures on total gas and methane production of the diet are shown in Table 4. It can be seen from the table that biomass resources and processing temperatures affected total gas production $(\mathrm{ml} / \mathrm{gDM})$ at 4,24 and 48 hours of incubation $(P<0.02)$. Interactions between biomass resources and processing temperatures affected total gas production at 4 hours $(P=0.06)$ and 24 hours $(P=0.001)$, but not at 48 hours $(P=0.531)$. Biomass resources and processing temperatures affected methane production $(\mathrm{ml} / \mathrm{gDM})$ at different incubation times, except the effect of biomass resources on methane production at 24 hours $(P=0.406)$. Interactions between biomass resources and processing temperatures affected methane production at 4 and 48 hours $(P<0.001)$, but not at 24 hours $(P=0.096)$. Gas and methane production were greater for corncob-derived biochar than its rice straw and bamboo tree $(P<$ 0.05). Increased processing temperature from 300 to $700^{\circ} \mathrm{C}$ reduced total gas and methane production at different incubation times $(P<0.05)$.

Biomass resources and processing temperatures and their interactions affected the ratio between methane and total gas after 4 hours of incubation. However, they did not have any effects after 24 and 48 hours of incubation $(P>0.05)$.

\section{In vitro digestibility, $\mathrm{pH}$ and $\mathrm{NH}_{3}-\mathrm{N}$ concentration}

Effects of biomass resources, processing temperatures and their interactions on in vitro digestibility, $\mathrm{pH}$ and $\mathrm{NH}_{3}-\mathrm{N}$ concentration (mg/100ml) are shown in Table 5. In vitro DM and OM digestibility and $\mathrm{NH}_{3}-\mathrm{N}$ concentration increased with incubation time. Biomass resources, processing temperatures, and interactions affected DM digestibility after 24 and 48 hours of incubation $(P<0.05)$. Biomass resources affected OM digestibility after 4 and 24 hours of incubation, but it was not the case after 48 hours. Processing temperatures and their interaction with biomass resources affected OM digestibility after 48 hours of incubation $(P<0.001)$.

Biomass resources, processing temperatures and their interactions affected $\mathrm{pH}$ at different incubation time, except at 24 hours when biomass resources did not affect the $\mathrm{pH}$ of incubation. $\mathrm{pH}$ at 4 and 48 hours of incubation was higher for rice straw than corncob and bamboo tree $(P<0.05)$. Increased processing temperatures decreased $\mathrm{pH}(P<0.05)$. Biomass resources and processing temperatures independently affected $\mathrm{NH}_{3}-\mathrm{N}$ concentration after 24 and 48 hours of incubation $(P<0.001)$. $\mathrm{NH}_{3}-\mathrm{N}$ concentrations at 24 and 48 hours of the incubation were greater for corncob compared to rice straw and bamboo tree $(P<0.05)$. Similarly, $\mathrm{NH}_{3}-\mathrm{N}$ concentration at 24 and 48 hours of incubation was greater for rice straw than a bamboo 
tree $(P<0.05)$. Increased processing temperatures resulted in higher $\mathrm{NH}_{3}-\mathrm{N}$ concentrations at 24 and 48 hours of the incubation $(P<0.05)$.

\section{Discussion}

Methane production from ruminant livestock should be minimised in order to contribute to sustainable agriculture and climate change mitigation. There have been several nutritional strategies to reduce methane production from ruminants. Biochar supplementation to ruminants' diets has attracted significant concerns recently. Supplementing biochar (with and without biochar, different levels of biochar) has shown to decrease from 5 to $25 \%$ methane production, both in vitro and in vivo experiments ${ }^{7-10}$. Different types of biochar used in different experiments were probably the reason for this high variation of methane reduction. Biochar characteristics can vary with biomass resources and pyrolysis procedures, leading to differences in rumen fermentation and gas and methane production ${ }^{12}$. Therefore, we hypothesised that biochars produced from different tropical biomass resources and at different processing temperatures have different characteristics, thus manipulating rumen fermentation and methane production.

In this study, biochar produced at higher temperatures had a larger surface area and higher water holding capacity. When processing temperature increased from 300 to $700^{\circ} \mathrm{C}$, biochar surface area increased from 2.7 to $211.6 ; 1.1$ to 98.6 ; and 5.4 to $154.2 \mathrm{~m}^{2} / \mathrm{g}$, respectively for rice straw, corncob and bamboo tree; water holding capacity was increased from 4.8 to 6.6 ; 3.2 to 5.5 ; and 3.6 to 5.8 , respectively (Table 1 ). This confirms the findings of Bonelli et al. ${ }^{13}$.This is most likely due to the decomposition of organic matter and the formation of micropores, as explained by Katyal et al. ${ }^{14}$. In addition, according to Shaaban et al. ${ }^{15}$, a higher pyrolysis temperature causes the release of volatile matter and creates more pores. Moreover, Chen and Chen ${ }^{16}$ declared that the destruction of aliphatic alkyls and ester groups, as well as the exposure of the aromatic lignin core under higher pyrolysis temperatures, may result in increased surface area. According to Ghani et al. ${ }^{17}$, at lower pyrolysis temperatures, less than $500^{\circ} \mathrm{C}$, lignin is not converted into a hydrophobic polycyclic aromatic hydrocarbon, and biochar becomes more hydrophilic. At higher pyrolysis temperatures, more than $650^{\circ} \mathrm{C}$, biochar is thermally stable and becomes more hydrophobicity.

Increased processing temperature reduced total gas and methane production at different incubation times (Table 4). This results from increasing surface area and water holding capacity when biochar is produced at a higher temperature. Biochar with a larger surface area absorbs and adsorbs more gasses and/or methane ${ }^{5,7}$. In addition, methanotrophic proteobacteria and methanogenic archaea are the key bacteria responsible for methane production. Increasing the methanotrophs group increases methane oxidation, thus reducing methane accumulation ${ }^{18}$. In the rumen, biochar supplementation provides habitat and stimulates methanotrophic growth, thus reducing methane accumulation ${ }^{6}$. Furthermore, biochar produced from high pyrolysis temperature has high electrical conductivity and electron buffering capacity of fodder decomposing redox reactions ${ }^{11}$.

Biomass sources affected total gas and methane production. Corncob produced higher total gas and methane production than rice straw and bamboo tree derived biochars (Table 4). This is probably due to the smaller surface area and water-holding capacity of corncob derived biochar than its rice straw and bamboo 
tree counterparts. Effects of biomass resources on total gas and methane production were not consistent in the literature. Cabeza et al. ${ }^{9}$ reported that biochar prepared from Miscanthus reduced total gas and methane to the greatest extent and biochar prepared from rice husk and softwood pellets were least effective. Hansen et al. ${ }^{7}$ reported that straw-derived biochar numerically reduced methane to a greater extent than wood-derived biochar. However, Calvelo Pereira et al. ${ }^{19}$ did not find any differences in total gas and methane production between wood and crop residue derived biochar (i.e. corn stover and pine wood chips). McFarlane et al. ${ }^{12}$ found no effects of biomass resources (Chrestnut, Yellow Poplar, White Pine) on gas production. Calvelo Pereira et al. ${ }^{19}$ and Gurwick ${ }^{20}$ found no clear relationships between biochar chemical composition and in vitro total gas and methane production. This may explain for non-effects of biomass resources on total gas and methane production. According to Teoh et al. ${ }^{21}$, the variable success rate of past biochar studies at reproducing significant methane mitigation has largely been attributed to variation in biochar properties such as the particle size, adsorptive potential, electrical conductivity, and ability to act as an electron mediator in redox reactions during digestion.

In this study, biomass sources affected DM digestibility at 4, 24 and 48 hours and OM digestibility at 4 and 24 hours of the incubation. Processing temperature affected DM digestibility at 4, 24 and 48 hours, and OM digestibility at 48 hours of the incubation. Effects of biochar supplementation to diets on DM and OM digestibility were not consistent in the literature. Winders et al. ${ }^{10}$ could not find differences in DM and OM digestibility between two levels of 0.8 or $3 \%$ biochar supplementation. This was also confirmed by Hansen et al. ${ }^{7}$. According to Teoh et al. ${ }^{21}$, supplementing up to $800 \mathrm{mg} /$ day hardwood biochar over a 15 day period did not affect DM digestibility. Teoh et al. ${ }^{21}$ also argued that biochar is $100 \%$ inorganic matter and not metabolised by the rumen microbiota. However, Saleem et al. ${ }^{22}$ found improved DM and OM digestibility when biochar was supplemented to diets. They explained that biochar encourages biofilm creation, which stimulates the growth of desirable microbes by providing a niche for their continued proliferation. On the contrary, McFarlance et al. ${ }^{12}$ found reduced DM digestibility when biochar was supplemented with the level of $81 \mathrm{~g} / \mathrm{kg} \mathrm{DM}$. The authors argued that the inconsistent findings were due to differences in biomass sources, particle size, and pyrolysis conditions.

The $\mathrm{pH}$ and $\mathrm{NH}_{3}-\mathrm{N}$ are important parameters regulating rumen fermentation. Therefore it is important to study the effects of biochar supplementation on the $\mathrm{pH}$ and $\mathrm{NH}_{3}-\mathrm{N}$. Literature shows the effects of biochar supplementation and sources on the $\mathrm{pH}$ and $\mathrm{NH}_{3}-\mathrm{N}$ concentration. For example, Zhang et al. ${ }^{23}$ declared that biochar supplementation leads to increased $\mathrm{pH}$ value due to the alkaline nature of the biochar. Mirheidari et al. ${ }^{24}$ reported a stable of ruminal pH due to the lack of changes in primary ruminal fluid VFA, acetic and propionic concentrations among treatments of 0 (no added biochar; control), $1 \%$ walnut shell biochar (WSB), $1 \%$ pistachio by-product biochar (PBB), and 1.5\% chicken manure biochar (CMB). Cabeza et al. ${ }^{9}$ reported a reduction in ruminal $\mathrm{pH}$ and $\mathrm{NH}_{3}-\mathrm{N}$ concentration when biochar was prepared from Miscanthus straw, oilseed rape straw and softwood pellets at $1.16 \%$ of feed substrate were added to incubations. However, Mirheidari et al. ${ }^{24}$ reported that the inclusion of WSB, PBB and CMB increased ruminal $\mathrm{NH}_{3}-\mathrm{N}$ concentration by $34.5 ; 25.06$ and $18.89 \%$, respectively. 
In this study, a higher processing temperature decreased the $\mathrm{pH}$ and increased the $\mathrm{NH}_{3}-\mathrm{N}$ concentration after 24 and 48 hours of incubation. We expected a reduction of $\mathrm{NH}_{3}-\mathrm{N}$ concentration when biochar was produced at a higher temperature because of its larger surface area, which can adsorb more $\mathrm{NH}_{3}-\mathrm{N}$. However, it was not the case in this study. This can be explained. Effects of biochar on the $\mathrm{pH}$ and $\mathrm{NH}_{3}-\mathrm{N}$ concentration also depend on the archaeal and bacterial rumen microbiota, the fungal community structure, VFA concentration. In this study, those criteria were not measured. Future studies should analyse the rumen archaeal, bacterial, and fungal microbiotas, VFA concentration. Another speculation is that $\mathrm{NH}_{3}-\mathrm{N}$ concentration also depends on (i) proteolysis and deamination of nitrogen constituents in the substrate and (ii) incorporation of $\mathrm{NH}_{3}-\mathrm{N}$ into microbial protein or combine the two processes. Increased biomass processing temperature resulted in reduced gas production, which is the energy supply for microbial growth. This can be the reason for increasing nitrogen deamination to provide energy for microbial growth. This process releases $\mathrm{NH}_{3}-\mathrm{N}$, which results in a higher $\mathrm{NH}_{3}-\mathrm{N}$ concentration.

\section{Methods}

The experimental protocols were approved by the Faculty of Animal Sciences and Veterinary Medicine, Hue university of Agricultrure and Forestry (HUAF). The experiment used four fistulated beef cattle for rumen fluid collection. The working with animal procedures followed the Ethical guidelines and approved by the Animal Ethics Committee of Hue University, Hue city, Vietnam (Decision number: VNHU0009). The study is reported in accordance with ARRIVE guidelines.

\section{Materials}

The experiment was done at the Faculty of Animal Sciences and Veterinary Medicine Lab Centre, HUAF, Hue city, Thua Thien Hue province, Vietnam. Three tropical biomass resources were used for producing biochars including rice straw, corncob and dry bamboo tree. They are availabe materials in Vietnam, all of them were collected from the Central region, Vietnam and stored at the Faculty of Animal Sciences and Veterinary Medicine, HUAF before biochar was produced. Each biochar type was produced at three processing temperatures $\left(300,500\right.$ and $\left.700^{\circ} \mathrm{C}\right)$. Biochars were produced as described by Nguyen et al. ${ }^{25}$.The chemical composition and characteristics of biochars are presented in Table 1. Remarkably, biochars produced from different tropical biomasses have differed in surface areas $\left(\mathrm{m}^{2} / \mathrm{g}\right)$, and increased processing temperatures resulted in increased surface areas of biochars.

\section{Experimental design}

A 3 biomass resources $x 3$ processing temperature factorial design was used to study the effects of biochars produced from rice straw, corncob and bamboo tree, produced at different processing temperatures on in vitro rumen fermentation characteristics and methane production. Biochar biomass resources included rice straw, corncob and bamboo tree and biochar processing temperature included 300,500 and $700^{\circ} \mathrm{C}$. Total gas and methane production, in vitro digestibility of dry matter (DM), organic matter (OM), and in vitro rumen fermentation characteristics ( $\mathrm{pH}$ and $\mathrm{NH}_{3}-\mathrm{N}$ concentration) were determined at three-time points $(4,24$ and 48 
hours of the incubation). Total 140 bottles ( 3 biochar resources $\times 3$ processing temperatures $\times 5$ bottles/treatment combination $\times 3$-time points and 5 bottles for 5 blank samples) were used for incubation.

\section{Rumen inoculum}

Rumen fluid was collected before the morning feeding on 4 fistulated beef cattle in the Faculty of Animal Sciences and Veterinary Medicine farm, Hue University of Agriculture and Forestry. Cattle were fed diets consisting of rice straw (50\%) and concentrate (50\%), concentrate comprising soybean meal (25\%), maise meal $(25 \%)$, rice bran $(30 \%)$ and cassava powder $(20 \%)$. After being collected, the rumen fluids were immediately transferred to the laboratory where the rumen fluid of 4 cattle was mixed and put in a warmed thermos flask $\left(39 \pm 0.5^{\circ} \mathrm{C}\right.$ ), and then filtered through 4 layers of cheesecloth to eliminate feed particles and then carefully mixed with the buffer mineral solution with a ratio of 1 part of rumen fluid and 4 parts of buffer solution. All operations were made under anaerobic conditions by flushing with carbon dioxide. Buffer mineral solution, as described by Theodorou et al. ${ }^{26}$ and was preheated in a water bath at $39^{\circ} \mathrm{C}$ and purged continuously with $\mathrm{CO}_{2}$ for 30 minutes.

\section{Substrates and chemical analyses}

The substrate ingredients are presented in Table 2. Added biochar occupied 3\% in the substrate (DM basis). Substrate samples were ground to pass a $1 \mathrm{~mm}$ sieve using a hammer mill (Pullerisette 19, Fritsch GmbH, Laborgeratebau, Germany) and analysed for their chemical composition: DM, OM, crude protein (CP), neutral detergent fibre (NDF). The chemical composition of the substrate is presented in Table 3.

\section{In vitro fermentation and fermentation attributes analyses}

$250 \mathrm{mg}$ of the air-dried substrate was incubated in $120 \mathrm{ml}$ bottles, which contained $25 \mathrm{ml}$ of mixed rumen fluid and buffer mineral solution. The total gas production was measured at 4, 24 and 48 hours during the incubation using a manual pressure transducer (Digitron 2023P, Digitron, Torquay, Devon, UK) combined with a syringe. Methane production was determined simultaneously by Gas chromatography (Model 8610C Gas Chromatograph, SRI instruments Europe GmbH, USA).

Digestibility of $\mathrm{DM}$ and $\mathrm{OM}, \mathrm{pH}$ and $\mathrm{NH}_{3}-\mathrm{N}$ concentration were determined at three-time points $(4,24$, and 48 hours of incubation). Each time, the $\mathrm{pH}$ value was measured immediately by a pH meter (Model HI8314, Hana, Rumania). Approximately $10 \mathrm{ml}$ of end liquids were sampled and divided into aliquots for downstream $\mathrm{NH} 3-\mathrm{N}$ concentration analyses after being equally mixed with $0.2 \mathrm{M} \mathrm{HCl}$. The rest of the end liquids in each bottle were centrifuged at $10.000 \mathrm{xg}$ for 5 minutes. The supernatant was removed and dried at $105^{\circ} \mathrm{C}$ for 12 hours and burned at $550^{\circ} \mathrm{C}$ for 4 hours to determine DM and ash concentration. Digestibility of DM and OM were calculated as the difference of weight before and after the incubation, corrected by blank samples, which consisted of five flasks containing only buffered rumen fluid. $\mathrm{NH}_{3}-\mathrm{N}$ concentration was measured by the method of AOAC (1990).

\section{Statistical analyses}

The effects of biomass resources and processing temperatures on total gas and methane productions, in vitro digestibility of $\mathrm{DM}, \mathrm{OM}$, and in vitro rumen fermentation characteristics ( $\mathrm{pH}$ and $\mathrm{NH}_{3}-\mathrm{N}$ concentration) 
were analysed using ANOVA of SPSS 16.0. with the following model.

$Y_{i j k}=\mu+B_{i}+T_{j}+B_{i}^{*} T_{j}+e_{i j k}$

Where $Y_{i j k}$ is the observation from bottle $j ; \mu$ is the overall mean; $B_{i}$ is the effect of biomass resources; $T_{j}$ is an effect of processing temperature; $B_{i}{ }^{*} T_{j}$ is an interaction between biomass resources and processing temperature; $\mathrm{e}_{\mathrm{ijk}}$ is the residual effect. Tukey test was used for pairwise comparison between two treatments when the $P$ value of the $\mathrm{F}$ test was $<0.05$. In all the analyses, significant effects were declared at $P<0.05$.

\section{Declarations}

\section{Acknowledgements}

The authors wish to thank the National Foundation for Science and Technology Development (NAFOSTED), Vietnam for their support and funding of this project (Code 106.05-2019.22).

\section{Author contributions}

Dinh Van Dung and Le Duc Thao: Data curation, Writing - Original draft preparation. Le Dinh Phung: Conceptualization, Writing - Reviewing and Editing. Le Duc Ngoan: Reviewing and Editing. Hynek Roubík: Conceptualization, Reviewing and Editing.

\section{References}

1. Hristov, A. N., Oh, J., Lee, C., Meinen, R., Montes, F., Ott, T., Firkins, J., Rotz, A., Dell, C., Adesogan, A., Yang, W., Tricarico, J., Kebreab, E., Waghorn, G., Dijkstra, J. \& Oosting, S. Mitigation of greenhouse gas emissions in livestock production: A review of technical options for non-CO2 emissions. Edited by Gerber P. J., Henderson, B. \& Makkar H. P. S. FAO Animal Production and Health, Paper No. 177, FAO, Rome, Italy (2013).

2. Tapio, I., Snelling, T. J., Strozzi, F. \& Wallace, R. J. The ruminal microbiome associated with methane emissions from ruminant livestock. J. Anim. Sci. Biotech. 8(1), 7 (2017).

3. Johnson, K. A. \& Johnson, D. E. Methane emissions from cattle. J. Anim Sci. 73, 2483-2492 (1995).

4. Boadi, D., Benchaar, C., Chiquette, J \& Massé, D. Mitigation strategies to reduce enteric methane emissions from dairy cows: Update review. Canadian J. Anim. Sci. 84, 319-335 (2004).

5. Lehmann, J. \& Joseph, S. Biochar for environmental management: An introduction. In: J. Lehmann \& S. Joseph, editors, Biochar for Environmental Management. Science and Technology London. 1-12 (2009).

6. Leng, R. A., Inthapanya, S. \& Preston, T. R. Biochar lowers net methane production from rumen fluid in vitro. Livest. Prod. Sci. 24(6) (2012a).

7. Hansen, H. H., Storm, I. M. L. D. \& Sell, A. M. Effect of biochar on in vitro rumen methane production. Acta Agri. Sca. Sec. A-Anim. Sci. 62, 305-309 (2012).

8. Leng, R. A., Preston, T. R. \& Inthapanya, S. Biochar reduces enteric methane and improves growth and feed conversion in local "Yellow" cattle fed cassava root chips and fresh cassava foliage. Livest. Res. 
Rural Devel. 24(11) (2012b).

9. Cabeza, I., Waterhouse, T., Sohi, S. \& Rooke, J. A. Effect of biochar produced from different biomass sources and at different process temperatures on methane production and ammonia concentrations in vitro. Anim. Feed. Sci. Technol. 237, 1 - 7 (2018).

10. Winders, T. M., Jolly-Breithaupt, M. L., Wilson, H. C., MacDonald, J. C., Erickson, G. E. \& Watson, A. K. Evaluation of the effects of biochar on diet digestibility and methane production from growing and finishing steers. Trans. Anim. Sci. 3(2), 775 - 783 (2019).

11. Sun, T., Levin, B. D. A., Guzman, J. J. L., Enders, A., Muller, D. A., Angenent, L. T. \& Lehmann, J. Rapid electron transfer by carbon matrix in nature pyrogenic carbon. Nature Commu. 8(1), 14873 (2017).

12. McFarlane, Z. D., Myer, P. R., Cope, E. R., Evans, N. D., Bone, T. C., Biss, B. E. \& Mulliniks, J. T. Effect of biochar type and size on in vitro rumen fermentation of orchard grass hay. Agri. Sci. 2(8), 316-325 (2017).

13. Bonelli, P. R., Buonomo, E. L. \& Cukierman, A. L. Pyrolysis of surgarcane bagasse and co-pyrolysis with argentinean subbituminous coal. Ener. Sour. 29, 731- 740 (2007).

14. Katyal, S., Thambimuthu, K. \& Valix, M. Carbonisation of bagasse in fixed bed reactor: influence of process variables on char yield and characteristics. Ren Ener. 28, 713 - 725 (2002).

15. Shaaban, A., Se, S. M., Dimin, M. F., Juoi, J. M., Husin, M. H. \& Mitan, N. M. M. Influence of heating temperature and holding time on biochars derived from rubber wood sawdust via slow pyrolysis. J. Analy. Appl. Pyro. 107, 31 - 39 (2014).

16. Chen, B. \& Chen, Z. Sorption of naphthalene and 1-naphthol by biochars of organge peels with different pyrolytic temperatures. Chemosphere. 76, 127 - 133 (2009).

17. Ghani, W. A. W. A. K., Mohd, A., de Silva, G., Bachmann, R. T., Taufiq-Yap, Y. H., Rashid, U. \& Al-Muhtaseb, A. H. Biochar production from waste rubber-wood-sawdust and its potential use in $\mathrm{C}$ sequestration: chemical and physical characterisation. Indust. Crops. Prod. 44, 18-24 (2013).

18. Man, K.Y., Chow, K.L., Man, Y. B., Mo, W. Y. \& Wong, M. H. Use of biochar as feed supplements for animal farming. Critical Rev. Envir. Sci. Technol. 51(2), 187-217 (2021).

19. Calvelo Pereira, R., Muetzel, S., Camps Abestain, M., Bishop, P., Hina, K. \& Hedley, M. Assessment of the influence of biochar on rumen and silage fermentation: a laboratory scale experiment. Anim. Feed. Sci. Technol. 196, 22 - 31 (2014).

20. Gurwick, N. P., Moore, L. A., Kelly, C. \& Elias, P. A systemaric review of biochar research, with a focus on its stability in situ and its promise as a climate mitigation strategy. PloS One. 8(9), (2013).

21. Teoh, R., Caro, E., Holman, D. B., Joseph, S., Meale, S. J. \& Chaves, A. V. Effects of hardwood biochar on methane production, fermentation characteristics, and the rumen microbiota using rumen simulation. Frontiers. Micro. 10, 1534 (2019).

22. Saleem, A. M., Ribeiro Jr, G. O., Yang, W. Z., Ran, T., Beauchemin, K. A., McGeough, E. J., Ominski, H. K., Okine, E. K. \& McAllister, T. A. Effect of engineered biocarbon on rumen fermentation, microbial protein synthesis, and methane production in an artificial rumen (RUSITEC) fed a high forage diet. J. Anim. Sci. 96(8), 3121 - 3130 (2018).

23. Zhang, M., Li, J. H., Wang, Y.C. \& Yang, C. M. Impact of different biochar types on the anaerobic digestion of sewage sludge. RSc Advances. 9, 42375-42386 (2019). 
24. Mirheidari, A., Torbatinejad, N. M., Shakeri, P. \& Mokhtarpour, A. Effects of biochar produced from different biomass sources on digestibility, ruminal fermentation, microbial protein synthesis and growth performance of male lambs. Small Rumi. Res. 183,1-6 (2020).

25. Nguyen, X. L., Do, P. T. M., Nguyen, C. H., Kose, R., Okayama, T., Pham, T. N., Nguyen, P. F. \& Miyanishi, T. Properties of biochars prepared from local biomass in the Mekong delta, Vietnam. BioResources. 13(4), 7325 - 7344 (2018).

26. Theodorou, M. K., Williams, B. A., Dhanoa, M. S., McAllan, A. B. \& France, J. A sample gas production method using pressure transducer to determine the fermentation kinetics of ruminant feeds. Anim. Feed Sci. Technol. 48, 185-97 (1994).

\section{Tables}

Table 1. Chemical composition of biochar produced from tropical rice straw, corncob and bamboo tree at different processing temperatures. $R$ rice straw, $C$ corncob, $B$ bamboo, $D M$ dry matter, $O M$ organic matter, $W C$ water capacity.

\begin{tabular}{|llllllllll|}
\hline Items & $\mathrm{R}$ & \multicolumn{3}{c|}{$\mathrm{C}$} \\
& $\mathrm{R} 300$ & $\mathrm{R} 500$ & $\mathrm{R} 700$ & $\mathrm{C} 300$ & $\mathrm{C} 500$ & $\mathrm{C} 700$ & $\mathrm{~B} 300$ & $\mathrm{~B} 500$ & $\mathrm{~B} 700$ \\
\hline $\mathrm{DM} \%$ & 98.0 & 94.7 & 96.6 & 99.7 & 93.9 & 97.5 & 99.1 & 95.3 & 95.9 \\
\hline Ash \% & 18.0 & 17.3 & 21.3 & 3.6 & 3.5 & 3.9 & 9.5 & 10.5 & 11.4 \\
\hline $\mathrm{OM} \%$ & 82.0 & 82.7 & 78.7 & 96.4 & 96.5 & 96.1 & 90.5 & 89.5 & 88.6 \\
\hline $\mathrm{WC}$ & 4.8 & 4.4 & 6.6 & 3.2 & 3.4 & 5.5 & 3.6 & 3.9 & 5.8 \\
\hline $\mathrm{C} \%$ & 61.0 & 62.4 & 69.4 & 67.1 & 66.1 & 59.3 & 57.2 & 59.1 & 56.8 \\
\hline $\mathrm{H} \%$ & 1.9 & 1.6 & 1.4 & 2.0 & 2.5 & 1.7 & 1.7 & 2.9 & 2.0 \\
\hline $\mathrm{O} \%$ & 10.6 & 10.2 & 8.7 & 11.3 & 12.6 & 7.8 & 6.5 & 5.0 & 7.9 \\
\hline $\mathrm{N} \%$ & 0.7 & 0.7 & 0.6 & 0.5 & 1.0 & 0.8 & 0.5 & 0.7 & 0.3 \\
\hline $\mathrm{P}_{2} \mathrm{O}_{5} \%$ & 1.0 & 0.7 & 0.6 & 0.8 & 1.0 & 0.6 & 0.6 & 1.0 & 1.0 \\
\hline $\mathrm{K}_{2} \mathrm{O} \%$ & 0.6 & 0.7 & 0.7 & 0.6 & 0.7 & 0.4 & 0.9 & 0.7 & 0.6 \\
\hline Surface area $\mathrm{m}^{2} / \mathrm{g}$ & 2.7 & 15.7 & 211.6 & 1.1 & 7.1 & 98.6 & 5.4 & 63.0 & 154.2 \\
\hline $\mathrm{pH}$ & 8.78 & 8.91 & 9.02 & 8.99 & 8.97 & 9.21 & 9.22 & 9.03 & 8.99 \\
\hline
\end{tabular}

Table 2. Substrate ingredients (\% of DM basis) 


\begin{tabular}{|ll|}
\hline Ingredients & $\%$ \\
\hline Rice straw & 50 \\
\hline Soybean meal & 15 \\
\hline Maize meal & 12 \\
\hline Rice bran & 10 \\
\hline Cassava powder & 10 \\
\hline Biochar & 3 \\
\hline
\end{tabular}

Table 3. Chemical composition of substrates when supplemented with $3 \%$ biochar. $R$ rice straw, $C$ corncob, $B$ bamboo, $D M$ dry matter, $O M$ organic matter, $C P$ crude protein, $E E$ ether extracts, $N D F$ neutral detergent fibre.

\begin{tabular}{|llllllllll|}
\hline Items & $\mathrm{R}$ & \multicolumn{3}{c}{$\mathrm{C}$} \\
& $\mathrm{R} 300$ & $\mathrm{R} 500$ & $\mathrm{R} 700$ & $\mathrm{C} 300$ & $\mathrm{C} 500$ & $\mathrm{C} 700$ & $\mathrm{~B} 300$ & $\mathrm{~B} 500$ & B700 \\
\hline DM \% & 88.5 & 89.5 & 89.2 & 88.7 & 89.6 & 89.9 & 88.8 & 89.6 & 89.4 \\
\hline Ash \% & 9.11 & 7.98 & 8.51 & 9.69 & 7.75 & 7.63 & 9.15 & 8.15 & 8.19 \\
\hline OM \% & 90.9 & 92.0 & 91.5 & 90.3 & 92.2 & 92.4 & 90.8 & 91.8 & 91.8 \\
\hline CP \% & 12.0 & 11.7 & 12.2 & 12.4 & 11.4 & 11.8 & 11.7 & 11.7 & 12.1 \\
\hline EE \% & 3.90 & 3.74 & 3.30 & 4.50 & 4.26 & 3.68 & 4.50 & 4.37 & 3.72 \\
\hline NDF \% & 57.2 & 51.5 & 46.7 & 52.9 & 50.1 & 52.0 & 50.1 & 50.7 & 54.2 \\
\hline
\end{tabular}

Table 4. Effects of biochar produced from tropical rice straw, corncob and bamboo tree at different processing temperatures on in vitro total gas and methane production at 4, 24 and $48 \mathrm{~h}$ after incubation. $R$ rice straw, $C$ corncob, $B$ bamboo tree, Bio biomass resource, $T$ temperature, Biox $T$ interaction between biomass resource and temperature, $S E M$ standard error of mean with $\mathrm{df}_{\text {error }}=36,{ }^{\mathrm{a}-\mathrm{c}}$ Means within rows and within each factor without a common superscript letter are different at $P<0.05$. 


\begin{tabular}{|c|c|c|c|c|c|c|c|c|c|c|}
\hline \multirow[t]{2}{*}{ Items } & \multicolumn{3}{|c|}{ Biomass sources } & \multicolumn{3}{|c|}{ Temperature level } & \multirow[t]{2}{*}{ SEM } & \multicolumn{3}{|l|}{$p$-value } \\
\hline & $\mathrm{R}$ & C & B & 300 & 500 & 700 & & Bio & $\mathrm{T}$ & $\begin{array}{l}\text { Bio } x \\
\text { T }\end{array}$ \\
\hline \multicolumn{11}{|c|}{ Gas production $\mathrm{ml} / \mathrm{gDM}$} \\
\hline $4 \mathrm{~h}$ & $30.4^{b}$ & $33.7^{\mathrm{a}}$ & $30.6^{b}$ & $33.3^{\mathrm{a}}$ & $31.3^{b}$ & $30.1^{c}$ & 0.222 & $<0.001$ & $<0.001$ & 0.060 \\
\hline $24 \mathrm{~h}$ & $141.7^{\mathrm{b}}$ & $151.9^{a}$ & $140.6^{\mathrm{b}}$ & $151.0^{\mathrm{a}}$ & $147.5^{\mathrm{b}}$ & $138.8^{\mathrm{C}}$ & 0.574 & $<0.001$ & $<0.001$ & 0.001 \\
\hline $48 \mathrm{~h}$ & $220.5^{b}$ & $231.3^{\mathrm{a}}$ & $221.1^{b}$ & $231.5^{\mathrm{a}}$ & $226.4^{\mathrm{a}}$ & $215.0^{b}$ & 1.416 & 0.002 & $<0.001$ & 0.531 \\
\hline \multicolumn{11}{|c|}{$\mathrm{CH}_{4}$ production $\mathrm{ml} / \mathrm{gDM}$} \\
\hline $4 \mathrm{~h}$ & $4.17^{\mathrm{ab}}$ & $4.30^{\mathrm{a}}$ & $4.10^{\mathrm{b}}$ & $4.54^{\mathrm{a}}$ & $4.25^{b}$ & $3.75^{\mathrm{c}}$ & 0.034 & 0.039 & $<0.001$ & $<0.001$ \\
\hline $24 \mathrm{~h}$ & 21.7 & 22.5 & 21.6 & $23.5^{\mathrm{a}}$ & $22.4^{\mathrm{a}}$ & $20.6^{\mathrm{b}}$ & 0.334 & 0.406 & $<0.001$ & 0.096 \\
\hline $48 \mathrm{~h}$ & $30.8^{\mathrm{b}}$ & $34.6^{\mathrm{a}}$ & $31.3^{\mathrm{b}}$ & $34.2^{\mathrm{a}}$ & $32.4^{\mathrm{b}}$ & $30.1^{c}$ & 0.172 & $<0.001$ & $<0.001$ & $<0.001$ \\
\hline
\end{tabular}

Table 5. Effects of biochar produced from tropical rice straw, corncob and bamboo tree at different processing temperatures on in vitro digestibility, $\mathrm{pH}$ and $\mathrm{NH}_{3}-\mathrm{N}$ concentration. $R$ rice straw, $C$ corn cob, $B$ bamboo tree, Bio biomass resource, $T$ temperature, Bio $\times T$ interaction between biomass resource and temperature, $S E M$ standard error of mean with $\mathrm{df}_{\text {error }}=36,{ }^{\mathrm{a}-c}$ Means within rows and within each factor without a common superscript letter are different at $\mathrm{P}<0.05$ 


\begin{tabular}{|c|c|c|c|c|c|c|c|c|c|c|}
\hline \multirow[t]{2}{*}{ Items } & \multicolumn{3}{|c|}{ Biomass sources } & \multicolumn{3}{|c|}{ Temperature level } & \multirow{2}{*}{ SEM } & \multicolumn{3}{|l|}{$\mathrm{p}$-value } \\
\hline & $\mathrm{R}$ & C & B & 300 & 500 & 700 & & Bio & $\mathrm{T}$ & Bio $\times T$ \\
\hline \multicolumn{11}{|c|}{ DM digestibility \% } \\
\hline $4 \mathrm{~h}$ & $21.5^{a}$ & $20.6^{\mathrm{b}}$ & $20.3^{b}$ & 20.5 & 20.5 & 21.4 & 0.119 & $<0.001$ & 0.051 & 0.149 \\
\hline $24 \mathrm{~h}$ & $51.7^{\mathrm{a}}$ & $50.2^{b}$ & $53.5^{\mathrm{c}}$ & $50.8^{c}$ & $52.8^{\mathrm{a}}$ & $51.9^{\mathrm{b}}$ & 0.144 & $<0.001$ & $<0.001$ & 0.021 \\
\hline $48 \mathrm{~h}$ & $56.6^{a}$ & $54.3^{b}$ & $55.4^{\mathrm{C}}$ & $54.2^{b}$ & $56.1^{\mathrm{a}}$ & $56.0^{a}$ & 0.167 & $<0.001$ & 0.022 & 0.006 \\
\hline \multicolumn{11}{|c|}{ OM digestibility \% } \\
\hline $4 \mathrm{~h}$ & $22.8^{\mathrm{b}}$ & $25.9^{\mathrm{a}}$ & $23.0^{\mathrm{b}}$ & 24.0 & 23.8 & 24.0 & 0.188 & $<0.001$ & 0.783 & 0.781 \\
\hline $24 \mathrm{~h}$ & $54.5^{\mathrm{b}}$ & $54.0^{\mathrm{b}}$ & $55.7^{a}$ & 55.0 & 55.5 & 54.6 & 0.191 & 0.001 & 0.572 & 0.918 \\
\hline $48 \mathrm{~h}$ & 58.4 & 58.4 & 58.4 & $59.2^{\mathrm{a}}$ & $58.8^{\mathrm{b}}$ & $57.2^{c}$ & 0.071 & 0.979 & 0.001 & 0.001 \\
\hline \multicolumn{11}{|l|}{$\mathrm{pH}$} \\
\hline $4 \mathrm{~h}$ & $6.93^{a}$ & $6.81^{b}$ & $6.85^{\mathrm{ab}}$ & $6.89^{a}$ & $6.91^{\mathrm{a}}$ & $6.79^{b}$ & 0.017 & 0.008 & 0.007 & 0.015 \\
\hline $24 \mathrm{~h}$ & 6.71 & 6.69 & 6.68 & $6.73^{a}$ & $6.70^{\mathrm{a}}$ & $6.45^{\mathrm{b}}$ & 0.009 & 0.196 & 0.002 & 0.022 \\
\hline $48 \mathrm{~h}$ & $6.66^{\mathrm{a}}$ & $6.63^{b}$ & $6.63^{b}$ & $6.69^{a}$ & $6.64^{\mathrm{a}}$ & $6.59^{b}$ & 0.005 & 0.007 & $<0.001$ & $<0.001$ \\
\hline \multicolumn{11}{|c|}{$\mathrm{NH}_{3}-\mathrm{N}$ concentration $\mathrm{mg} / 100 \mathrm{ml}$} \\
\hline $4 \mathrm{~h}$ & 5.24 & 5.26 & 5.33 & 5.21 & 5.28 & 5.33 & 0.044 & 0.645 & 0.560 & 0.249 \\
\hline $24 \mathrm{~h}$ & $7.84^{\mathrm{b}}$ & $8.24^{\mathrm{a}}$ & $7.59^{c}$ & $7.71^{\mathrm{a}}$ & $7.88^{\mathrm{a}}$ & $8.04^{\mathrm{b}}$ & 0.038 & $<0.001$ & $<0.001$ & 0.054 \\
\hline $48 \mathrm{~h}$ & $8.13^{b}$ & $8.45^{\mathrm{a}}$ & $8.03^{c}$ & $8.04^{\mathrm{a}}$ & $8.22^{b}$ & $8.33^{c}$ & 0.019 & $<0.001$ & $<0.001$ & 0.186 \\
\hline
\end{tabular}

